\title{
ADMINISTRATIVE REGULATION IN COMPARATIVE PERSPECTIVE
}

\author{
Fritz Morstern MarX*
}

I

Comparing is a means toward understanding. This being so, we may expect to enhance a proper assessment of administrative regulation by looking at the record of foreign experience. Perhaps there are lessons that deserve consideration-or cautions, or hints. Even a dull tracing of parallels may help to clarify trends and tendencies.

For obvious reasons, however, comparison is most fruitful when its object does not change from place to place. To a rider, the care of his horse is likely to be of considerable concern. But he would not get much enlightenment from inquiring into the treatment of man's mount elsewhere if man's mount elsewhere happened to be an elephant, or a camel, or a burro. In its most precise meaning, perhaps, administrative regulation as talked about in the United States does pose the same problem. In certain respects, it is something peculiarly home-grown. It may be too American for comparative examination to yield a full harvest.

The implications of such doubt are enlarged when one remarkable thing is borne in mind. It comes to light in the fact that the prevailing mode of reference in the United States links administrative regulation with the imposition of authority over economic interests, with the powers of government as they affect business. Administrative regulation thus is focused primarily on statutory clauses, public agencies, and official procedures, on the one hand, and on economic practices, on the other. Surprisingly little attention, by and large, has been given to the social matrix of administrative regulation, even to its basic ends. The degree to which administrative regulation is-or ought to be-an expression of government's fundamental concern with order, so as to provide a favorable environment for the unfolding of man's creative resources, is rarely placed under the magnifying glass. Much less is made of the significance of regulation as the essence of organized group life, of society itself, separate from government as its policeman, promoter, equalizer, and repairman.

For these reasons, it is probably useful to begin our brief exploration of comparative perspectives with some reflections on the social roots of regulation. As the organized state, for all practical purposes, is the bringer as well as the guardian of law, so is the state the source of formal regulation. But such formal regulation, in

- J.D. 1922, University of Hamburg, Germany. Professor of Political Science and Dean of Administration, Hunter College. Formerly Ford Foundation Research Professor in Governmental Affairs, Princeton University. Author, The Administrative State: AN Introduction to Bureaucracy (I957). Editor, Elements of Public Administration (rev. ed. 1959); Foreign Governments: The Dynamics of Polmics Abroad (rev. ed. 1952). Contributor to legal periodicals. 
the last analysis, represents the more or less adept management of society's inherent regulatory urge. Underneath all regulation is man's elementary need for obtaining, as a minimum, a suitable balance of advantage and disadvantage from the rewards and risks of group living.

What is a suitable balance, at least in minimal terms? Who is to be the judge? Man singly cannot prevail in this allocation of benefits and sacrifices, except as the tyrant or the demagogue. So he seeks strength, safety, and comfort by getting on the bandwagon of dominant community mores and sentiments, by accepting the guidance of the sense that seems common. Such guidance stems in part from individual foresight and group experience, but has other sources as well. It may flow, in part, from superstitions; or it may have crystallized, in part, in traditions; or it may be, in part, the output of opinion-manufacture, engaged in by the few to exploit the many; or it may express, in part, concepts of celestial partisanship to which human beings must bow reverentially.

These and similar influences spin the fabric of regulation. They furnish answers about right and wrong. They have produced in the United States that most extraordinary, well-nigh pornographic body of regulatory provisions aimed at chaperoning sex-provisions having more rather than less of a bite when made to snap at victims but highly selectively. The local interplay of these influences explains why there may be a difference of twenty years behind bars depending on whether seduction is proved in one state of the union or another, as Morris Ernst once concluded. ${ }^{1}$

When we turn from society's ceaseless efforts in weaving the web of regulation to those of government, it becomes clear at once that the most pervasive factor consists of the close relationships between both areas. But government is a structure designed to integrate the forces of society, to bring about civic commitments, to provide the forms available for legitimate public action. In its own structure, government, therefore, lays out channels of group influence and, consequently, strategic points of control.

It follows that the representative system, together with its obscure alley-ways, becomes the terrain in which political field commanders move their troops for closely calculated victories, often quite independent of what the public wants. The regulatory propensity of society may thus be diverted by an adroit superimposition of group goals, as in the case of the American Medical Association, to name a single but striking illustration. In the sphere of governmental activity, much depends on how articulate groups are, whether they are sufficiently well-off to make themselves heard widely, and whether the general public has discerning ears. Conversely, much depends on the counterweight of a common rationality, a "public philosophy" in Walter Lippmann's sense, ${ }^{2}$ and the capacity of the party system for evolving programs having broad appeal.

\footnotetext{
${ }^{1}$ Ennst, The Kinsey Report and the Law, 70 Scientific Monrmir 279, $28 \mathrm{r}$ (1950). Sec also 2 Sidney Post Simpson \& Julius Stone, Cases and Readings on Law and Society ro33 n.i (1949).

${ }^{2}$ Walter Lippanne, Essays in the Public Philosophy (1955).
} 
From this vantage point, we come to a view of regulatory agencies different in many respects from that encouraged by prevailing nomenclature. On the primary level, and putting it quite abstractly, society itself is a regulatory agency of vast importance. In more concrete manifestation, as something harnessed by human wills in order to attain specific objectives, regulatory agencies are characterized by a more sharply delineated focus of interest as well as by greater attention to organizational form.

But these agencies are by no means all governmental. Many are private in nature. Of these, some attempt a type of self-government of particular occupations. But one must not overlook the more familiar categories of interest groups, ranging from churches or patriotic societies to trade associations and labor unions. Such agencies generate power as a consequence of their very existence and in proportion to their basic strength. Thus, part of the regulatory capacity of society comes to lodge within them.

Either as an outcome or as an activity, regulation, therefore, resembles a contest between sources of influence. Of necessity, the regulated are simultaneously regulators in a real sense, and the center of gravity - or the actual locus of regulatory power-is shifting in some ways all the time. Expressed differently, to assume that only public agencies are engaged in administrative regulation is to restrict the field of vision beyond all reason.

Indeed, for the most part, the failure of public agencies to pursue their regulatory mandate with sufficient energy can be traced to a latent veto emanating from society itself. Nominal authority parceled out to governmental agencies is frequently immobilized by conflicting regulatory dispositions embodied in private agencies. The aims as well as the scope of administrative regulation may thus be said to be the object of a continuing disputation among the participants of the regulatory process. Thesis and antithesis seem drawn together in a single corpus, as it were.

By comparison with such a condition of near-equilibrium of public and private agencies, the regulatory pattern may demonstrate under other conditions the militancy of a popular movement, of an emotional drive, even of a venerated formula. Something like this is in evidence in the evolution and the stature of France's droit administratif. Originally the result of a revolutionary upsurge against the domination of administrative power by an unsympathetic judiciary, hailed as a liberation of the people's prerogative from its enslavement to the judges, the new administrative law had a populist aura that gave it ideological substance. As a consequence, private as well as public agencies fitted themselves into the magnetic field left by the French Revolution of ${ }_{17} 89$. The result has been that droit administratif, despite its aloofness from partisan causes and despite the change in regimes, remained all along on speaking terms with the common man. For its extensive area, administrative law reflected an unchallengeable settlement in the war of purposes, public and private, an element of the active constitution. It maximized the guidance 
needed by public agencies and minimized the interposing power of private agencies. In short, it served as a source of effective social discipline.

But France is here no more than a respected voice in a continental European chorus. No less pertinent are the comparable institutions of other countries, including the German example, built about the Rechtsstaat idea as the most tangible safeguard of legality for the "ordinary man" when he felt the grip of administrative power. There may be little in this concept that is not equally implicit in the Anglo-American version of the "rule of law." The difference in the practical significance of the two lies in the impact upon administrative regulation. In a nutshell, with us, a Hewart of Bury ${ }^{3}$ or a Roscoe Pound, ${ }^{4}$ with bravoes from the legal profession, might step forth to exorcise the demons of bureaucratic arrogance. In Germany, the Rechtsstaat idea became a powerful factor in the orientation of the bureaucracy itself, a binding standard of lawful action and concern with right germane to the outlook of a self-conscious middle class.

II

We reminded ourselves of the regulatory urge that rises within society from its very nature in order to stress the derivative character of governmental regulation. Without the first, the second would lack foundation. Society produces the sound, so to speak, and government the echo. But such a statement requires qualification to match the facts without distortion. Being organized rather than organic, being established rather than grown, government serves as a man-made instrument of purpose. If society is what's in the kettle, government is the spout, together with the hand that does the pouring. Unfortunately for competent pouring, however, the spout may be split as well as full of holes; and instead of one hand, there may be haphazard grappling of many.

Measured by the equivalent of splits and holes and hands, then, the operational effectiveness of government can be appraised over a hypothetical range ascending from bottom to top. As an active force, government-or the state, to use once more the classical language of political theory-is not a constant, but a variable, which, in turn, is profoundly affected by other variables, political, economic, and social. Granting that much, it is self-evident that the same must be true of regulation. Whatever the legal prescription for the mechanics of the regulatory process, of critical significance for the character of its performance is its general environment, the "parallelogram of forces" about it.

Ultimately, of course, regulation is to provide the signposts of human behavior. But the purpose may be defeated when there are too few or too many such posts; or when it becomes a national sport to push them over; or when they are habitually ignored, though kept in place, as if for decoration. The attitude of most Americans toward the Eighteenth Amendment at the height of the campaign against honest liquor is a case in point.

${ }^{3}$ Hewart of Bury, The New Despotism (1929).

'E.g., Roscoe Pound, Administrative Law: Its Growth, Procedure, and Significance (1942). 
Complete defeat of regulatory purpose is relatively rare under normal conditions of government in the contemporary western style. But there is much ground to traverse between such defeat and the often naively assertive language of administrative regulation. Between these two poles, one encounters the evidence of relative success that may be claimed for different regulatory patterns. Here, then, are found the telling differences of degree-distinctions that run far less frequently to white and black than to varying shades of grey. In spotting these differences, we are bound to deal, time and again, with a considerable array of variables. Indeed, each characteristic of a given regulatory prototype continuously evolves its variants in terms of more or less.

The civic acceptance and thus the basic efficacy of administrative regulation are linked in a primary way with several factors. One worth mentioning first is the degree to which the public at large is inclined to identify itself with government, as the agency of the common good. That is partly a matter of constitutional arrangements for political participation of the citizenry in the determination of general policy. Partly it has to do with the relative standing of private enterprise and public enterprise in the forum of mass opinion. And partly it is the result of the institutional resources commanded by government, of its capacity for accomplishing what it sets out to do, of the intellectual equipment of its public service.

In such combination of ingredients, a country like Sweden, for instance, would rate toward the top. She has long enjoyed an easier synthesis in her national life than would have been conceivable in the United States, granting its historic evolution, especially during the nineteenth century. It is, therefore, not surprising that Swedish administrative law, despite the essential simplicity of its conceptual structure, reflects a high degree of social consciousness and sophistication-qualities that have often been stressed by as great an authority as Professor Herlitz. ${ }^{5}$

Another factor relevant to our discussion is the degree to which government succeeds in unifying the pluralistic drives and tensions of society. To acknowledge this aim is not to deny the essentially plural nature of any aggregation of human beings, each sewn into his skin, each lastly the captive of his self. Man may seek to tranquilize himself under layers of woolly "togetherness," but will yet continue to turn into an obstreperous nuisance in the most elementary group processes when his changing moods so prompt him and his restraints give way. However, by accepting the fact that society is plural of necessity, we merely emphasize the correlating task of government. The many must manage to be one, for certain purposes and on certain occasions; and to do that, they must work toward being one by learning to move in formations. When government does not rise above the diversity of society, it sacrifices its organizing purpose. It fails to furnish common denominators for social advance as well as for order and freedom. It leaves the cooperative energies of society without a formula to provide direction.

\footnotetext{
'See, e.g., Herlitz, Swedish Administrative Law: Some Clzaracteristic Features, in 3 Scandinavian STUDIES IN LAW 87 (I959).
} 
Here, again, the variables of more or less are in evidence. The pluralism of interests may largely remain unmitigated for want of a party system strong enough to become the taskmaster of utilitarian union. If there is such a party system, it is likely to force the interests into coalitions and alliances that in themselves amount to a first-level coordinating effort. Party programs push what is special toward an acknowledgment of what is joint and even what is general, at least within the kinship order that connects compatible special interests, whether one thinks of the economic, the social, or the broadly cultural realm.

When party programs serve to bring and hold together certain interest groupings, when each comes to respect a common bond uniting it with certain others if only pragmatically, the program of a party is bound to follow it into the driver's seat. Party programs, in so far as they signify a coalescence of kindred interests around mutually desirable political objectives, are fit to be converted into governmental programs when the party is carried into power. Programs that convey marching orders for political action are like current running through the entire structure of government. One dominant impulse simultaneously actuates both legislation and administration. Then the approach of a particular regulatory agency cannot be expected to be self-centered and insular. On the contrary, it will operate in the stream of government-wide responsibility, be, therefore, more visible to the public eye, and consequently itself gain in sense of responsibility.

When painting with a broad brush, one has to sacrifice, to some extent, the finer shadings. Contrasts are often sharpened beyond the point of impeccable accuracy. It is, therefore, well to remember that in the process of comparison, we are substituting repeatedly rough approximations of reality for the precise verification of each factual component. But such approximations are quite satisfactory for our present purposes. Even when one talks in approximations, it is easy to recognize the validity of contrasting an institutionally unified political system, relatively speaking, with one that generates divisive forces by its own design, again relatively speaking.

The United States belongs in the second category. The Founding Fathers proved unwilling to plan either for themselves or for those groups closest to them a role of assured elitarian domination. They planned instead against domination itself. Federalism, the separation of powers, the dual structure of the legislature, the opportunity for judicial challenge of every type of authority-all these militate against an easy attainment of the integrating function of government. None of the instrumentalities of division has merely negative implications. Each has contributed values that have been entered on the ledger of American growth. But there is no question that, precisely for the same reason, the United States has periodically been agitated by the impatient quest for a true pattern of public responsibility. At progressively shorter intervals, the same battle cry was heard. There was to be an end to the fragmentation of power, to the escape from answerability, to the reckless scattering of government's precious capacity for action in the general interest. 
For a long time, America's political image-to use a term lately touched by too many unwashed hands-was overwhelmingly custodial. It was centered on the preservation of "soundness" as the "consensus" of a raw, yet creative enterprise society. Such preservation did not require strong arms. Rather, it was to be accomplished by the massive weight of an acquiescing attitude. In these circumstances, the outline of public responsibility could well stay blurred. When it comes to deploying the forces of government for action, for the achievement of objectives given priority by being part of a program, responsibility must be poised in an ascending order, as a rationally intelligible structure. When the pressure of weight suffices, responsibility can afford to be diffuse--if it is still properly called responsibility.

As long as the custodial function of government was dominant, and as long as the "consensus" of society, in turn, dominated that function, the specific operations of public agencies did not matter greatly. For the most part, they could be left to political patronage. A new class of middlemen had come forth. Although habitually derided as "politicians," they had one redeeming grace. No one could blame them for being in the middleman's business for the sake of business. But they could be trusted, by and large, to respond instinctively to "soundness," to the "consensus" of society, especially to the property symbolism. There was nothing decadent about it. When Lincoln Steffens pitted his moral determination against the "bosses," he could not fail to discover at last that he was confronting the vitality of Henry Clay's "American System."

Small wonder that the reform movement in the early decades of our century preached concentration of responsibility, together with a professionalization of the public service. If these had not been goals in conflict with the buccaneering habits of party machines, the American people might have been spared the high-class passion for "nonpartisan" partisanship. As it was, such leaders as Charles E. Hughes, Elihu Root, and Henry L. Stimson, each uncommitted to a party gospel, had to make their own way in battling against the old political order. ${ }^{7}$ They addressed themselves to reshaping the "consensus" of society, without attempting to blow new life into the limp body of the party system.

What has emerged from the reform movement is difficult to overestimate. Broadly speaking, it is the gradual fashioning of the essential equipment for reasonably effective government in the United States in the face of twentieth-century needs. The markstones stand out in time, slow as the development might seem to the impatient. Igo6 saw the beginnings of the New York Bureau of Municipal Research, the first significant venture in cooperation between public-spirited business captains and the new professionals in administrative analysis. ${ }^{8}$ In I9I7, the state

${ }^{\circ}$ See Lincoln Steffens, The Struggre for Self-Governmient (Ig06).

${ }^{7}$ See Henry L. Stimson \& McGeorge Bundy, ON Active Service in Peace and War (i948); see also Harlan B. Phimlips (ed.), Felix Frankfurter Reminisces (1960).

${ }^{a}$ See N.Y. Bureat of Municipal Research, Six Years of Munictpal Research for Greater New YORK: RECORD FOR I906-I9II (I9I2). The Bureau's working approach was described as "that of patient, scientific inquiry and genuine helpfulness." Citizen Agencies for Research in Government, Municipal Research, no. 77, Sept. 1916, p. x. As William H. Allen, one of the founders of the Bureau expressed it: 
of Illinois brought the critically important function of budgetary planning and fund control directly under the governor, as a "strong executive." Four years later, in I92I, Congress passed in virtual unanimity a piece of legislation that aimed in the same direction, but actually reached out much farther. It managed to hide its quasi-constitutional impact behind the opaque designation of Budget and Accounting Act. ${ }^{9}$

The Act did set up badly needed fiscal machinery for estimates review, expenditure control, and independent audit. Much more far-reaching, however, were four other features of the law. In the first place, responsibility for providing Congress through the annual budget with a comprehensive and integrated plan of operations for the federal government was squarely put upon the President. But this time a solemn invocation did not seem enough. Words had failed in earlier laws to prompt deeds. The Act, secondly, took care of this difficulty by placing at the President's elbow a thing stuffed with potentialities, something that in any such explicit form had not existed before. The new thing was a staff agency, the Bureau of the Budget, exclusively under the President's command, to help him with the chores of his office, in the wider executive as well as in the budgetary spheres. The position of Budget Director was so designed in law as to make him in every sense "the President's man," leader of a continuing professional staff, a presidential fact-finder who would furnish direction over this staff from the angle of the President.

Thirdly, the Budget and Accounting Act made it expressly a duty of the new bureau to engage in management analysis and to conduct administrative studies in particular federal agencies. This was more than a matter of ampler jurisdiction. Rather, by doing so, the Act caused the budget agency to lift its eyes above accounting sheets, toward the functioning of the apparatus available for accomplishing the President's program and toward the problems to be solved as well. And lastly, the Act provided a foundation for turning the Budget Bureau at the same time into the President's clearing house for legislation. In reviewing legislative proposals, session upon session, the Bureau again was encouraged to temper the negative predisposition of a financial watchdog with careful consideration of the legislative means for carrying forward the President's policies. The Budget Bureau's responsibility was as much oriented toward getting things done as it had to do with control over spending.

III

Why these observations about administrative growth? Simply to make very clear that Government in the United States has radically changed its operating style

\footnotetext{
"Every public administrative centre should have a fact centre." William H. Allen, Efficient DeMOCRACY 26I (I907). The ideal of "efficiency" was captivating at that time not only the world of business, but also other realms. Thus, Professor William H. Allison declared: "The essential apostolic qualification in American Baptist polity has been efficiency." Allison, The Basis of Baptist Polity, [Baptist] Standard, March 30, 1907, p. 923. See also Shailer Mathews, Scientific Management in THE ChURChes (r912).

- For the budgetary development in relation to executive responsibility, see Morstein Marx, The Bureau of the Budget: Its Evolution and Present Role, 39 AM. PoL. Scr. Rev. 653, 869 (1945).
} 
since the Interstate Commerce Commission struggled through its first day of business in 1887 . It is in our own century that the Presidency has come to the fore as a unique institution of governmental cohesion and program coordination, besides revealing itself as a vast repository of political strength. It is in our own century that American public administration has assumed truly professional characteristics, in both day-by-day competence and intellectual resources employed for policy planning. It is in our own century that the staff organization available to the President himself has attained a high degree of institutional maturity. Past and present are set apart. It is for these reasons that the view of American government and administration that is still prevalent in so many places abroad is hopelessly outdated.

Although it is hard to say how America sees itself today in the governmental dimension, one thing is quite certain. The administrative realities of the midtwentieth century leave little of the incoherent theory that nurtured the nineteenthcentury American approach to administrative regulation. Above all, the promise of impregnability against partisan inroads, assurance of expertship, and institutional autonomy that was advanced by the concept of the so-called independent regulatory commission would not survive immediate challenge if it were to come up in our day as a fresh idea. Indeed, to put it bluntly, were it conceivable that the regulatory pattern in the United States had yet to be made at this hour, free from the burden of what has become distressingly familiar from the past, a groping for solutions on the model of such commissions or boards would seem highly unlikely.

However invigorating the Jacksonian movement had been as a breakthrough of popular rule, the deterioration of government's administrative performance that accompanied it proved to be an enormous liability. The pervasive consequences of political patronage as a common means of filling political offices made administrative agencies ineffectual rather than responsive to the people's will. The decades after the Civil War showed federal administration in a condition of ineptness and lethargy. If one had to live with the still debatable idea that interstate rail transport needed the federal government's attention, something more seemed necessary than the unenlightened ways of a patronage bureaucracy. From this vantage point, it was realistic to look for a new mechanism equal to the large task to be attempted.

In the circumstances, then, it was not illogical to assume that regulation of a sensitive sector of the economy called for a special instrument. Partisanship in the spoils tradition would not do. Nor would ignorance and bungling on the part of unskilled officials. Neither did it appear tolerable at the opening of the regulatory era to expose the ministrations of the expert's hand to the dangerous contagion of loose-jointed administrative practice in the central departments, on the one hand, or to the manipulative grip of the President as chief executive, on the other. The independent regulatory commission, if implanted in the no-man's-land between legislation, administration, and justice, promised to be exactly the right answer to these specifications.

But change in later decades has been sweeping. With the Presidency as the main- 
spring of administrative energy in the national government and with the federal service a career establishment of recognized attainments and still greater potentialities, the independent regulatory commission is now becoming a museum exhibit. Politically, it has shown itself an easy touch for greedy fingers, largely because of the ambiguities that surround its purpose as well as its status. The isolation of its existence, away from the general concerns of the executive branch, makes it timid, stodgy, and slow. The discipline of commitment to a government-wide program is lacking, and with it a sense of common urgency. Moreover, collegial management, despite some recent strengthening of the chairman's arm, has continued to be mostly a burden on good administration.

This is not the place to enter into a detailed examination of what ails the independent regulatory commission. What is important is to bear in mind that the pattern of administrative regulation in the United States evolved from the deficiencies in the general style of departmental operations. Conversely, the changed character of administrative performance cannot be left aside. In the day of the "service state," government is reduced to a rather limited choice. It can either develop within its own cadres the resources needed for effective administrative regulation, or it must allow those to be regulated to settle down on its back.

These considerations are reinforced by a look at other administrative systems, especially those that matured at an earlier date. In France, in Brandenburg-Prussia, and even in England, the adaptation of governmental processes to the evolving requirements of an economy acquiring urban-commercial characteristics occurred under auspices of monarchical power, in the shadow of the rising nation-state. Its backbone was an integrated order of offices, especially on the European continent. A single administrative apparatus was built up, as the unifying instrument of the crown. It was manned by "king's men," chosen for competence as well as loyalty, a novel standing army pledged to serving the new state-the forerunner of today's merit bureaucracy. Thus, government staked out its managerial claims. The eighteenth century witnessed the consolidation of effective administration in Prussia and Austria. Shortly afterward, the Napoleonic era carried France toward the same goal. And England followed suit in the midnineteenth century, by laying the foundation for the modern British civil service-so long a gleam in the eye of American spokesmen of reform.

As administrative regulation in Europe geared itself for the pressures of the industrial age, it represented a pretested pattern. A search for expertise combined with institutional staying power was bound to lead back to the normal working methods of the public service. The writings of administrators around the turn of the eighteenth century, for the most part distinguished by both an eminently practical approach and a philosophical disposition, attest the degree to which competence in thought and action had come to lodge in administrative offices. The essential unity of the departmental system was becoming a continuing concern of the emerging career service. At the same time, professionalized administration grew 
conscious of its assets. It saw itself-and was generally respected by the public-as a body knowledgeable in the ways of achieving policy goals by organizational as well as procedural means; divorced from the interests that wrestled with one another for influence and accommodation; and able to stand its ground in the storms of politics.

The administrative systems of Europe, especially those of the continent, achieved a respectable degree of effectiveness before the same condition was attained generally in the United States. With us, in the 'eighties, to accomplish the application of expertise in a novel venture such as the regulation of the railroads, it seemed best to break out of the bounds of the departmental structure. Outside, the air appeared fresher and cleaner. Outside, there was the chance of an uncontaminated start. In Europe, by contrast, the regulatory approach was woven into the operational heritage of government. It was at the very heart of the administrative process. To insure resourceful regulation meant to rely on the familiar methods of familiar public agencies, staffed by men trained to administer.

No new device was needed. What was needed-and what unfolded, stage by stage, during the first half of the nineteenth century-was a fully developed pattern of redress against administrative determinations. Characteristically, it was a pattern general in scope rather than confined to particular governmental functions. It was informal, rather than weighted down with procedural ritual. It operated in a manner informed rather than legalistic. And its benefits remained within the reach of the ordinary mortal's pocket, rather than being accessible only to those who need not limit their interest in relief from unwarranted impositions because of economic pressure to avoid considerable costs.

Thus, the problems of administrative regulation were seen abroad mainly as problems of public accountability. They were not seen primarily as problems of organizational structure or agency procedure. The emphasis was on the general law of administration as a source of authority, and as a limitation of authority as well. But law amounts to little when it sleeps in peace. It needs to speak. Administrative law called necessarily for a spokesman. This spokesman entered upon the scene in the form of a specialized judiciary, of judicial bodies distinguished by thorough knowledge of the practical business of public administration.

It is difficult to imagine how the concept of a separate judiciary for disposing of citizens' suits against administrative agencies could have made much headway except for one critically important factor. That factor was the commitment of the ascending merit bureaucracy to the ideal of law and order, and thus to the ideal of limited authority. To say that this is an ideal peculiarly congenial to maturing merit bureaucracies is not to detract from the achievement. In a relatively primitive condition, bureaucratic elites are prone to view the free sway of administrative authority as the very foundation of law and order-and hence as its equivalent, even its essence. As their sophistication increases, and as the simplified formula of an earlier day has 
to be abandoned, they tend next to fall into escapist habits. The judicial test is too icy a shower, if it is not being dreaded as the fire of the purgatory itself.

This is an attitude typical of administrative systems that suffer from paucity of public esteem and, therefore, lack self-confidence. Fritz Fleiner, the great teacher of administrative law famed for his Institutionen, ${ }^{10}$ used to pour scorn on the reluctance shown by the Swiss civil service toward entering fully into the spirit of legal redress, even though the Free Confederacy can hardly be said to furnish a climate favorable to an authoritarian disposition. Similarly, the career man in Washington, more often than not, counts it as a victory when a judicial test of administrative power can be avoided. We need to add, perhaps, that the judgment of a court of law, to him, may seem vastly less predictable than the agreements coming forth from even an obscure alignment of forces in a congressional committee.

Droit administratif and its genuine counterparts elsewhere in the world reflect a higher stage of growth in the evolution of the merit bureaucracy. The administrative profession, in this stage, is ready to accept the idea of a legitimate grievance on the part of the individual. It undertakes to invite the actio popularis as a beneficial rod, to bow to the need for a legal defense in justification of its deeds, and to permit a free probing of the supporting arguments. Not surprisingly, this bent of mind was bound to produce a quasi-proprietary attitude toward administrative law within the career cadre. It was now a matter of honor, so to speak, to stay on the side of legality, even in the face of strong temptation to laugh off the judicial test. Dedication to the umpire's integrity of administrative law thus became the hallmark of the tried-and-true career man in public service.

These factors explain very largely why in France, in Germany, in Austria, and in other parts of continental Europe, it was the higher civil service that regarded itself as the pillar of administrative law. The elaboration of both the individual's sphere of guarded privacy and the governmental agency's range of authority could not have been accomplished as something external to the public service-and laid upon it like a yoke. Professional concern with the limits of administrative power and the extent of the citizen's rights transformed itself into an aspect of the official milieu. By becoming part of the bureaucratic culture, droit administratif and Verwaltungsrecht turned into a counterbureaucratic force, keeping the officialdom within the orbit of a common law that showed marked equalitarian tendencies and a sturdy sense of balance.

Other influences helped to amplify this general effect. One was the emphasis on legal knowledge in the academic preparation for the administrative career, though frequently a target for critics favoring, instead, a managerial orientation. Administrative law, in turn, rose to a higher and to a more compelling position in the general course of study required of every one for admission to the bar. Again, the higher civil service came to regard the law of administration as a branch of legal

\footnotetext{
${ }^{10}$ Fritz Fleiner, Institutionen des Deutschen Verwahtungsrechts (8th ed. 1928). This edition was a model of lucid exposition.
} 
knowledge specifically entrusted to its attention. It was not a matter of tolerable responsiveness to the need for legal counsel once the intrusion of such need into the busy day could no longer be ignored. Rather, the vital precepts of administrative law were absorbed into the thinking as well as the language of the merit bureaucracy itself. Indeed, they turned into a sort of password that made it easy to spot the truly professional man in administrative office.

As a result, the civilizing pressure of administrative law not only transformed raw bureaucratic power into an accountable agency of the community, but also penetrated equally into all of the continuing functions of government. Law and administration came to form a unity. Administrative law merged into the administrative way. This, once more, could hardly have happened if the arm of the law had reached into the utilitarian management of public affairs from the outside, like a cold pike. Happily, the organs of administrative justice, though independent of executive command, were drawing much of their judicial manpower from the ranks of the higher career service.

Administrative courts, for this reason alone, were well equipped for their role. They were arsenals of first-hand knowledge about administration. Such knowledge enabled them, in building up the case law of public management, to do two things simultaneously. One was the alert handling of issues where the individual needed protection but where the pursuit of the common good was not to be blocked categorically. Here the art of sure-handed reconciliation of seeming opposites was at a premium. The other-far more consequential for the entire development-was the prudent practice of supererogation in the theological sense, by molding constructive guidelines for use by the administrative profession in serving the public interest. After all, it was not a simple matter of slapping the hand of the public agency. It was the task of leading it toward that eminently practical goal-a synthesis of utility and legality, of public purpose and limited authority.

Any one could stop the show. But the show must go on-in government, too. What is required, in addition, is that it be a clean professional performance, joining together, within the bounds of legitimate concepts of feasibility, the proper interest of the individual and the ultimately overriding interest of the whole body politic.

\section{IV}

In the light of the continental European evolution of governmental institutions, it would seem odd to consider administrative regulation a thing distinguishable from the larger realm of public management. It would seem odder still to give the conduct of regulatory functions distinctive organizational form and to farm out the individual regulatory tasks to self-contained agencies insulated from the departmental system and thus off the highway of executive responsibility. If one were to probe these reactions in search of explanation, the answer likeliest to come forth would be the question: Can one conceive of a relevant difference between regulation and the normal work of administrative agencies? 
In exploring the nature of the judicial process, Benjamin Nathan Cardozo found it appropriate to begin by asking himself: What is it that I do when I judge ?11 In its flowering, the school of juridical realism in the United States drew much inspiration from operational perspectives like this. But Cardozo was far from presenting a particular school of legal theory, least that of the realists, who looked for the conceptual essence of law in the behavior of human beings who said that they applied the law. Even so, Cardozo saw good reason to illuminate the judicial function by an examination of what was being done about it in the course of its exercise. What do we discover when we adopt the same point of view toward administrative regulation?

Part of the answer has been given earlier. That answer was to say that to govern is to regulate. But a complete answer carries us farther. A complete answer might begin with the observation that to regulate is, in the first place, to scrutinize meanings. Practically speaking, all administrative regulation functions under the explicit or implicit direction of certain canons, criteria, standards, or policies. This, indeed, is true even as we ascend the steps of authority. Legislatures, far from being freely creative makers of regulatory pronouncements, are under comparable direction-by ideology, public expectancies, constitutional clauses, and the like. Constitutions, in turn, as they meet man's dreams, are bound to borrow from the sacred words of the particular age and often respond to the persistent whisper of ageless influences such as natural law-a great institution, though neither law, strictly speaking, nor in any way related to nature.

The problem of meanings is vital on all these different levels of authority. This is so because dispositional action-action affecting either the public at large or certain limited publics-is characteristically built on derived competence, on jurisdiction as well as functions circumscribed in language binding to the regulatory agency. What it has got to act with is passed down from farther up. To find out what it is requires reference to meanings employed at a higher point.

This consideration by itself does away with the idea that to regulate is to do as one pleases. To be sure, when power is forced into a structure of control, excessive and destructive tightness would develop, save for the immensely beneficial lubricant known as discretion. Generality and specificity, rule and case, must be brought together in a nexus both logical and satisfying in terms of the interests to be served. Here justice cannot afford to be blind. It must be seeing. Discretion is needed to fashion this nexus by working as the eye of justice.

To express it differently, discretion cannot be divorced from its purpose. It is not a three-hour pass to get away from the rule. It is, rather, the flying squad for the rule, to make its presence uniformly felt. Discretion, then, is the means of assuring that no case is dealt with except in relation to the rule, whatever the particular circumstances; and that such particular circumstances do find proper attention when otherwise the rule would turn into a mindless tyrant. That is why con-

\footnotetext{
${ }^{11}$ See Benjalin N. Cardozo, The Nature of the Judicial Process (1925).
} 
tinental European administrative law has given so much attention to defining the limits of lawful discretion, however "free," and to refining the test of motive as a principal instrument for dividing right from wrong. ${ }^{12}$

Administrative regulation aims at certain results. It seeks to create an institutional product, so to speak-that is, a specified behavior on the part of those being regulated, subject to enforceable public accountability. The primary method in turning out the institutional product of regulation is to haul in the pertinent facts, to analyze and evaluate them, to establish causal relationships as well as the means-end sequences, to spot alternatives of approach-all so as to do promptly and properly what needs to be done, under the agency's mandate. The emphasis is on doing, with the sheltering as well as restraining implication that what is proposed to be done can be justified.

But the business of regulation is not consummated in the act of justification. The latter is inferential to the former, and the lawyer gets into the act only in this inferential context, unless he contributes his skill to devising a sound regulatory line of action. Certainly, in many instances, the adequacy of empirical research on which the eventual decision comes to rest will be more significant for the outcome than purely legal considerations. This fundamental point, it will be recalled, eventually occurred some fifty years ago even to the very obdurate Professor Dicey, despite his profound misgivings about a thing as un-British as droit administratif...$^{13}$

What is still more important is that in looking at the methods employed by administrative regulation, we found nothing that could be called exclusive characteristics. Notice of intent and provision for hearing are auxiliary to arriving at a finding. It is the finding that is indispensable. In short, we have come to grips with the essence of the working approach of administration generally, rather than with a specific regulatory procedure, applicable here but nowhere else. In digging up the facts and reaching conclusions in the light of the empirical evidence, regulation does not do anything unfamiliar as part of the normal ways of administration. Nor can one discern any basic distinction in this respect between the fixing of railroad rates and the licensing of atomic reactors, between policing the security market and redressing the balance of payments, between allocating wave lengths and fighting an epidemic, between enforcing requirements of industrial safety and reducing crop surpluses.

In each of these examples, the first step is the accumulation of concrete information, so as to substitute light for obscurity. Next, the picture thus gained must be stripped of controversial features as far as possible. In allowing those being regulated the opportunity of an early challenge, before the last word is said, a useful corrective

\footnotetext{
${ }^{12}$ On the limits of lawful discretion, as they have evolved in continental European administrative law, see Morstein Marx, Comparative Administrative Law: A Note on Review of Discretion, $87 \mathrm{U}$. PA. L. REv. 954 (1939), Comparative Administrative Law: Economic Improvisation by Public Authorities, 88 id. at 425 (1940).

${ }_{13}$ Albert Venn Dicex, Introduction to the Study of the LAw of the Constitution foreword (8th ed. 1915).
} 
is introduced. Finally, reasonable safeguards must be provided to infuse into the emerging decision a responsible projection of the common good. The regulators are not meant to be merely negotiators between given interests. The decision is not meant to be merely an exercise in calculating pressures. The interest called general is not merely a mathematical function of special interests as they happen to intrude. That is why the career service needs fortitude as well as perception. But in all of this, again, we encounter simply an outline of how administration works, irrespective of its particular tasks, regulatory or other-or how it ought to work.

These, then, are the perspectives typical of the continental European attitude toward administrative regulation. Concisely put, one may sum it up by saying that to administer is to regulate. The regulatory approach is seen as implicit in the accomplishment of administrative purposes. Redress of regulatory impositions is, therefore, regarded as an incidental aspect in the use of general remedies against unlawful exercise of administrative power. The effectiveness of such remedies had to be assessed over the entire range of administrative functions and in regard to all forms of administrative actions, including those of a regulatory character.

In its most significant expression, pursuit of these generally available remedies, as mentioned earlier, placed the citizen in the care of a specialized judiciary-the administrative courts. As further pointed out before, the administrative courts viewed themselves as being entrusted with a kind of guardianship over both the law of administration and the conduct of administration according to law. The incisive and knowledgeable manner in which this guardianship was exercised helps to explain why, in turn, the internal procedures of administrative agencies came to reflect marked deference to legal requirements. But the sense of adequacy about the state of these internal procedures, especially for dealing with informal complaints, did not lead to a withdrawal into bureaucratic self-sufficiency. It did not dim the recognition that only a system of external review by administrative courts would supply the necessary capstone. Without an outside monitor, and one prepared to show the way, attention to legal guaranties might become slack in the activities of administrative agencies.

In this way, administrative law gained a dual locus. Internal agency procedures addressed themselves to the need for fairness in dealing with members of the public as well as for official accountability. In the last analysis, both served the purpose of keeping the house of administration clean. Appeals were opened up from the field-office level to the regional center and ultimately to the headquarters of a department. As a minimum, on complaint, the judgment of the administrative superior was brought into play. In more elaborate form, examination of the complaint might be a collegial process, perhaps by a three-man body, including representatives of the public, depending on the administrative operations in question. The pattern was not uniform in every detail. Different departments evolved different arrangements. But the concept of a remedial apparatus within the four walls of 
administration as an essential element in the discharge of governmental functions was accepted as commonplace.

Manipulation of this apparatus by the aggrieved citizen was made easy. It did not require adherence to a set procedure, with its pitfalls of technicality. A handwritten note or even an oral explanation was enough. The tendency for the administrative agency to find itself in the right upon internal review was counteracted by two important factors. In the first place, the complaint was potentially but the prelude to external reconsideration before the administrative courts, as the next stage. Internal review was, therefore, itself always on trial, as it might have to meet judicial eyes afterward. And secondly, the professional point of view of the administrative cadre translated itself into concern with the efficacy of the department's mode of operations. Complaints were an incentive toward testing once more the bolts and screws so vital for good administrative performance.

Administrative justice, as the sphere of the specialized judiciary, and attention to lawful and responsive procedure within the individual governmental agency, as part of the regular business of public administration, thus represented two different realms. But neither made the other superfluous. Each had its well-defined purpose.

To keep the utilitarian drives generated in administrative agencies firmly in harness, to hold authority within the limits drawn by law, to combat bureaucratic indifference as well as abuse-these were goals that had to be achieved, in the first instance, in the day-by-day operations of thousands of public offices. Yet, it was not enough to acknowledge the conviction that a decent effort was made in most of these offices to practice the maxim of government of laws. Administrative procedure was always in danger of relaxing into an ex parte parody of equity. Someone was needed to look in from the outside-one having the right to ask all kinds of questions, to examine all kinds of files, to weigh all kinds of explanations in complete independence from executive or legislative influence.

Separate-and separately necessary-as these two realms continued to be, they were joined by being proving grounds of a single organizing force, the indivisible body of administrative law. Moreover, the connections were reinforced by the human factor. The agency spokesman, for example, might be a more widely renowned authority on certain aspects of administrative law than any member of the panel of judges sitting in a particular case. Again, before being very far along in his career as a higher civil servant, the agency spokesman might be invited to change places. He might be called upon in the process of advancement to don the judicial robe for the remainder of his active years, taking his seat on an administrative court.

The two realms, then, were separate without lacking connections. Indeed, each existed for the other, in a sense. External review through administrative courts bolstered the legal instinct of public management. Conversely, the axiom that administration acquired its status as a civilized activity by proceeding on the path of law tremendously eased the tasks of the administrative courts. Instead of carrying 
the whole load, they could afford a selective approach, centered on the building of precedents.

\section{$\mathrm{V}$}

Like any body of law, administrative law is not safe from the threat of turning dry and falling dead. Why did continental European administrative law retain its élan vital for so long? Why did it continue to furnish administrative regulation a solid foundation even though over the last hundred years the rising industrial society posed always anew strikingly different problems to cope with and singled out ever-expanding fields for regulatory action?

Some of the reasons can be recognized without much difficulty. The early union of function and law, of action and restraint, produced a viable tradition, and one of great adaptability to the novel demands of the emerging service state. That the career man in administration usually brought a juridical sensitivity to bear upon his duties was another factor. That adjudication of conflicts between administrative agencies and private parties was in the hands of courts that knew the ways of officialdom was still another. More fundamentally, perhaps, administrative law gained its social rank by being the pedestal on which the modern merit bureaucracy assumed its posture as an integral element of the equalitarian constitutional order of the twentieth century.

One of the outstanding illustrations of a happy combination of these several factors is the French Council of State, the Conseil $d^{\prime}$ Etat. $^{14}$ It is both a central staff agency, especially in advising the cabinet on legislative proposals, and France's supreme administrative court. In this latter capacity, what is perhaps most remarkable is the deft blending of ingredients of competence as well as of procedure. On the first, it must be borne in mind that the Council's staff represents one of the top-ranking grand corps of the French civil service. Competition for entrance has long been vigorous. In gaining admission, juridical skill and administrative promise have traditionally been at a premium. It is quite common for the leading spirits in the Council of State to gain a place among the living authorities on droit administratif-unless they find it more fascinating to write on truly eternal subjects exemplified by young Léon Blum's Le mariage.

As one of the oddities of the reform measures adopted after World War II, legal training is now no longer required for entrance. This change was brought on by the establishment of the National School of Administration. The highest graduates of the exacting three-year course offered under auspices of the National School are privileged to knock at the door of the Conseil d'Etat without having delved far into administrative law. But the Council has quietly overcome this anomaly. In such case, an unofficial tutorial grooming will be provided by a designated legally trained

14 Perhaps the best English introduction into the work of the Conseil d'Etat is C. J. Hamson, Exrcutive Discretion and Judiciat Control: An Aspect of the French Conseil d'Etat (i954). See also Brian Chapman, The Profession of Government (1959). For a good concise statement, see Langrod, The French Council of State: Its Role in the Formulation and Implementation of Administrative Law, 49 AM. Pol. Scr. Rev. 673 (1955). 
staff member to close the gap. The results thus far, it must be admitted, are quite impressive.

It is hardly surprising that during the past 160 years the talent available in the Council has been drawn upon frequently. Staff members have been given a great variety of special assignments. These have led some into key posts of colonial administration and into other positions of an executive character. Moreover, members may go on the inactive list and remain there while serving, for instance, as elected deputies or in international bodies. It may be recalled that President De Gaulle's durable prime minister, Michel Debré, is a senior staff member of the Conseil d'Etat.

More frequent are short-term assignments, by official designation. These may consist of unraveling a difficult administrative situation in or out of Paris, presiding over eminent-domain proceedings for a controversial public project, carrying on delicate negotiations involving French interests in some foreign capital, or chairing a fact-finding body to sift a cluster of unpopular proposals. Much official experience is thus constantly being carried back into the judicial role of the Council of State.

Equally substantial are the procedural resources of the Conseil d'Etat. In its inner workings, one observes an intertwining of different mechanisms of scrutiny. Normally, the weeding out of the governing facts of every case up on appeal is entrusted to a reporter. It is his task to see to it that at no stage in the disposition of the case questions of fact arise that cannot be answered on the record he has assembled. The reporting task is completed with the concise exposition of all that is factually relevant before the section concerned with the case-a number of individuals sufficiently large to allow for diversity of personalities as well as of points of view.

The weight of the analytical job of penetrating into the legal issues raised by the case falls to the governmental commissary. He is normally a tower of juridical strength, a man of authority and encyclopedic knowledge, often esteemed both within and without the Conseil d'Etat. His task is to draw out the hidden implications, to reflect upon the series of applicable precedents, and to lay out the bricks and straws of a proposed decision. Again, this is done before the assembled section meeting in public. Needless to say, it does not matter that the visible public is less than all of Paris. It may consist, in fact, of no more than half a dozen individuals, including the inevitable old man who throughout the proceedings remains buried in his newspaper, turning the pages with unseemly rustling. The self-discipline emanating from a public proceeding is, nevertheless, present.

But there are still other roles in the review process that need to be sketched in. An important role is played by the president of the section, also mostly a great name. Although normally quietly attentive, he may have reason to invite clarification of particular points. Nor do things necessarily end in the section. Whenever there is need for it, especially in order to reconcile different views of different sections, 
a still larger forum is supplied in the form of a joint meeting of several sections or of the plenary session of the entire membership of the Conseil d'Etat.

In the operation of this machinery, one perceives an acknowledgment of the dimension of time. The Council, in pronouncing itself on what is law today, reaches back to what it found to be law in the past. Where it encounters a fork in the road, it also speculates about the likely requirements of the future. What is still more important, in the process of committing itself, the Council searches cautiously for the concert of minds in its midst. It strains to hear many voices rather than a single melody.

Individual responsibility and group responsibility are intermingled without stifling either. The tone of the proceedings is one of free inquiry, unburdened by disproportionate considerations of protocol, seniority, or prestige. For an old institution, this is cogent evidence of a youthful disposition, toward which René Cassin, the young old man so long at the helm of the Council, has made a great contribution. As a result of all these factors, what comes out of the Conseil d'Etat can well be called an embodiment of collective energies. It is representative of the spirit of the institution rather than of any one dominant mind.

Two additional points deserve mention. In the first place, despite the standing they enjoy, members of the Conseil d'Etat do not have individual offices, nor even working cubicles, a discomfort not as outrageous as it might appear to be to Americans when it is recalled that members of the British House of Commons are equally disadvantaged. Only the head of the Conseil d'Etat, designated as vice president under a nominal presidency, has his own office. On the other hand, it is obvious that for the same reason no staff member can hide within the institutional body itself. He cannot withdraw from his colleagues, except by working at home. When he is at the office, he does his work in the reasonably spacious library with heavily loaded shelves.

It is here that professional consultation takes place in whispered conversations that may go on for considerable time. It is here that ambiguities in legal clauses and past decisions are sounded out and fine points of meaning are argued soberly. With but slight exaggeration, one may say that the mind of the Conseil $d^{\prime} E t a t$ is being made up in the library. The principal means are an exchange of views among colleagues and quiet study of the printed page, file materials, or some draft paragraphs, usually still handwritten. In a sense, the Council is engaged in a perpetual conference.

Secondly, to stimulate among the membership of the Conseil d'Etat a comprehension of the many different questions coming up simultaneously before its several sections, a system of documentation has been built up. Case summaries and section agendas are prepared, which each member finds in his mail tray as he proceeds to the library. In this manner, an institutional mirror is held before the entire staff. Intellectual participation in what is going on at various points in the Palais Royal, the Council's nobly creaky quarters, is thus encouraged. The men and women in 
the service of the Council see about them not the impassive hauteur of abstract justice, but a breathing manifestation of law for all.

Here, then, is the vignette of a great administrative court. Perhaps its best self-portrait can be found in the ornate Livre Jubilaire ${ }^{15}$ commemorating, a decade ago, the I5oth anniversary of the Council's postrevolutionary reincarnation. Napoleon once said to one of his intimates that he never tired of taking his seat among the members of the Conseil d'Etat, even immediately upon return from a theater of war, because it was exciting to him to match his intelligence against the best minds of France and to find himself scoring well. It is this intellectual heritage that has fitted the Council for its historic mission as the molder of the law of administration and as the watchdog over arbitrary power-even under the first empire, even under Pétain.

To keep administrative justice an intellectual force as well as an agency of order and accountability has been recognized as a demand of necessity outside France as well. In Germany, for example, the link between the academic profession and the administrative courts has been a matter of tradition. The very concept of a specialized judiciary was picked up at an early date and carried forward toward practical application by political scientists as well as by teachers of public law. Juridical scholarship went far to open the terrain to the operations of administrative courts. It scraped the basic concepts clean, converted rulings into rules, and proceeded to erect a systematically arranged body of administrative law.

One beneficial effect was that the specialized judiciary was spared a great deal of agonized groping. Another effect was that the developing law of administration, though built up decision by decision, case by case, evolved a sense of inner coherence. It strove toward a grand design. In consequence, administrative law became greatly more teachable academically, thus progressively becoming more refinable. But the academic teacher was not only the instructor of his students. He also taught the practitioners of the administrative arts when reaching outside the lecture hall, especially as the author of treatises, monographs, and other professional writings. To a larger extent perhaps than most other fields of legal knowledge, administrative law invited methodical exposition. The great texts tended to be systems rather than compilations. They grouped the particulars and reached for the whole.

The fact that here, for once, the national context was less relevant left its imprint, too. Administrative law was a continental European common law, as it were. Intellectual interchange was thus made vastly simpler. In this respect, the Dane spoke the same language as the Argentinian, the Vietnamese the same as the Algerian. Many of the best-known works in the field reflected experience drawn from different areas. The classic example, no doubt, is the treatment of Verwaltungsrecht from the pen of Otto Mayer. Here was a man so endowed as to be unusually suc-

${ }^{15}$ LE ConseiL D'ETat, Ltvre JubrLaire (1952). The almost 700 closely-packed pages of this volume also contain a substantial section devoted to the influence of droit administratif on other parts of the world. 
cessful in forming a link between Germany and France. But Professor Mayer saw more than a joint interest and an identical outlook upon the danger of untamed power. He also recognized, earlier than others, that administrative law, in the day of positive government, was bound to become the prime instrument of the industrial society. After the first World War, when the political institutions of Europe had been drastically revised by history, Mayer remarked with uncanny astuteness in the introduction to the new edition of his book: "Constitutional law vanishes, administrative law remains." ${ }^{16}$

The German academic teacher, moreover, was not merely an organizer and an intermediary of knowledge. He was also pulled directly into the work of the administrative courts by combining the freedom of scholarship with service on the bench. While being made to give, he was allowed to take. Theory had its feet pulled down to the ground, and practice was not allowed to stagnate. Not all great teachers are great judges, but judges benefit from intermittent seminars in chambers. Tough thinking strengthens the sinews of justice.

This must suffice to delineate our subject. The institutional outline should be clear. What needs to be added is that the clarifying effect of an outline stems always in part from the bold strokes with which it is set forth. We have drawn a type, in a sense. But such is the perversity of human nature that it never tires of contradicting the typical. Hence, it is obvious that the type is continuously cut into and thus distorted by innumerable individual actions running counter to it. Moreover, to draw a type is not to claim perfection. As we said at the outset, each institutional characteristic provokes its variants. Ultimate appraisal of what presents itself as a type has to be in terms of varying degrees of the type's own self-fulfillment.

Granting all that, much is left to reflect upon. Culture patterns, it is true, do not encourage transplantations. To compare contains no commitment toward exchange. It does add a new brightness to the familiar. It may suggest a new direction in which to advance reconnaissance. It may prompt a turn of mind.

${ }^{10}$ Otto Mayer, Deutsches VerwaltungsRecht (1924). 